\title{
Alternative Financing Instruments for African Economies
}

\author{
Jane Mpapalika \\ UN Economic Commission for Africa (UNECA), Macroeconomic Analysis, Economic Governance and Public Finance (MGD) \\ Division, Addis Ababa, Ethiopia \\ Email: jane.mpapalika@un.org
}

How to cite this paper: Mpapalika, J. (2020) Alternative Financing Instruments for African Economies. Journal of Mathematical Finance, 10, 42-57.

https://doi.org/10.4236/jmf.2020.101005

Received: October 16, 2019

Accepted: January 13, 2020

Published: January 16, 2020

Copyright (c) 2020 by author(s) and Scientific Research Publishing Inc. This work is licensed under the Creative Commons Attribution International License (CC BY 4.0).

http://creativecommons.org/licenses/by/4.0/

\begin{abstract}
This paper investigates the alternative financing instruments that can be used to hedge sovereign risks and finance development in African countries. Many heavily indebted countries are exposed to external risks especially the exchange rate shocks due to limited use of hedging instruments. We propose alternative financing instruments to minimize sovereign risks and the cost of debt. Our paper uses the standard model for pricing options, the Black-Scholes model to determine the fair value of options. The findings show that barrier options have an added advantage over plain vanilla options because of its knock-ins and knock-outs features hence they are the most affordable to use. An important aspect of the effective debt management policies should be on developing local bond market to access alternative financing instruments in the world capital market.
\end{abstract}

\section{Keywords}

Financing Instruments, Sovereign Risks, Barrier Options, Pricing Options

\section{Introduction}

This paper investigates the alternative instruments of financing development and hedging risks in African countries. The limited hedging instrument in SubSaharan Africa has been a policy concern for foreign debt management since the 1980 's debt crisis. Many developing countries as pointed out by [1] Hussein and Mello (2001), are significantly exposed to exchange rate shocks. Hedging instruments reduce the cost of debt by minimizing the effect of external shocks. Persistent exposure to external shocks led to foreign debt accumulation in most of the African countries [2] [3] (Muhanji and Ojah, 2011, Mpapalika and Malikane, 2019). However, the limited use of hedging instruments due to underdeveloped local 
bond markets increases the exposure to external shocks. Accessing the world capital market as noted by [4] Daniel (2001) would supplement the existing instruments used for financing to reduce the sovereign risks.

The understanding of alternative financing instruments for hedging sovereign risks is important for policymakers. Managing sovereign risks will assist the policymakers in choosing cost-effective financial instruments to avoid sovereign defaults. Efficient debt management policies as noted by [5] Dooley (2010) should minimize the debt servicing costs and avoid debt instruments that are likely to cause defaults. The issuing of cost-effective debt instruments such as indexed bonds as suggested by [6] Lu and Neftci (2008), reduce government borrowing costs and the likelihood to default. Similarly, [7] Price (1997) note that indexed bonds are cost saving. From a policy perspective, financial instruments consistent with sound debt management practices should reduce the cost of borrowing and the default risks.

Despite the increase in financing needs, few studies focus on innovative financing and hedging instruments in African countries. Most studies, such as [8] Collier (2014), focus on the existing financing instruments in African countries e.g. public and private sector partnerships to finance its development. Other studies focus on the emerging market's financing instruments used by sovereign borrowers. Emerging market borrowers use alternative instruments embedded with innovative features to access capital market and diversify risks. Moreover, financial innovations assist borrowers to achieve lower cost of debt which yield higher returns. Therefore, the gap that this paper will fill is that there are limited existing studies on alternative financing instruments in Sub-Saharan Africa.

The main contribution is to assess the cost-effective instruments for hedging sovereign risks in African countries. This paper builds on the works of [6] $\mathrm{Lu}$ and Neftci (2008), who use the [9] Black-Scholes (1973) model to fairly price plain vanilla European options. The Black-Scholes model continues to be the standard option pricing model which is robust under the assumption of complete markets. We extend the model to African countries. The hypothesis made about the model is that the fair pricing of options will reduce the underlying risk of the associated asset.

The structure of the paper is as follows. Section 2 reviews the literature. Section 3 presents the theoretical framework. Section 4 describes data. Section 5 analyses the findings. Section 6 concludes with policy recommendations.

\section{Related Literature}

The literature on alternative financing instruments in Africa is relatively scarce. Most of the studies focus on the financing instruments in the emerging market economy. Alternative financing instruments issued in the international capital market are limited in African countries hence they are exposed to external shocks. Since developing countries are exposed to external shocks such as trade shocks, interest rate shocks as shown by [10] Cashin et al. (1999), [11] Kose and Riezman (2001), [2] Muhanji and Ojah (2011), alternative hedging instruments will 
minimize sovereign risks. According to [12] $\mathrm{Mu}$ et al. (2013), African bond markets are still small and underdeveloped to access hedging instruments that lower the sovereign default risks.

Another strand of studies show that sub-Saharan Africa's infrastructure needs are approximately USD 130 - 170 billion and a financing gap of $\$ 67.6-\$ 107.5$ billion annually. This increasing infrastructure gap has prompted African countries to reconsider the role of private sector participation in bridging the gap. Although, most of the sub-Saharan African countries with the exception of South Africa and Nigeria have not been able to attract significant private sector investment in different economic sectors. Moreover, the capacity to effectively construct, design and manage public private partnerships is a significant challenge across Africa. Only a few countries such as South Africa, Nigeria, Zambia, and Kenya have implemented PPP frameworks, however, these countries are still experiencing challenges in terms of resources and expertise. Importantly, for PPPs to be successfully across Sub-Saharan Africa, a sound policy, legal and institutional frameworks with clear guidelines and procedures for development and implementation of PPPs should be enforced. For instance, [13] Leigland (2018), noted that developing countries lag behind in the development of Public Private Partnerships because of the lack of a sound legal and institutional frameworks with which to implement such projects.

Some studies have investigated the role of indexed bonds in hedging risks as a useful tool for debt management. The government can hedge risks by issuing indexed bonds or shortening the maturity of domestic debt. Indexed bonds as pointed out by [7] Price (1997) are cost-effective in reducing government borrowing costs. For instance, the inflation-linked bonds which are financial instruments that tie their interest payment to price changes. Inflation-indexed bonds issued during periods of high inflation offset the debt burden by paying the inflation risk premium. If issuers are exposed to inflation risk, it might lead to a negative risk premium. If the issuer is risk neutral, the risk premium is likely to be positive. Inflation risks can be hedged by shortening the maturity of bonds denominated in foreign currencies.

A number of studies have investigated the issuing of bonds tied to their main export commodities. The issuing of commodity-linked bonds would reduce the debt burden along with declines in export prices. Developing countries should prefer issuing commodity-linked bonds than conventional debt to protect their export commodities from price volatilities. Commodity linked bonds such as gold-linked bonds as shown by [14] Atta-Mensah (2004) could be used as a financing means and as a hedge because it has the option feature. Since developing countries are exposed to substantial commodity price risks, [15] Myers (1992), note that they can use commodity-linked securities as a tool for risk management. Therefore, commodity-linked bonds are used for hedging commodity price shocks.

A related strand of literature focus on financing instruments in which the coupon payments are tied to the GDP of the issuing country. GDP-linked bonds 
have potential benefits as a financing instrument. Issuing a bond whose coupon payment is indexed to GDP growth is similar to issuing a plain vanilla option. According to [16] Schroder et al. (2004), GDP-linked bonds outperform conventional bonds because growth rate indexed bonds are associated with debt sustainability. Growth-indexed bonds have been suggested by [17] Chamon and Mauro (2006), as a way of reducing the likelihood of sovereign defaults. Despite their potential advantages, [18] Borensztein and Paolo (2004), note that growth-indexed bonds have disadvantage such the potential difficulties in pricing them.

Another strand of literature show that developing countries can use options whose value depend on the value of the underlying asset to hedge commodity price risks. The simplest financial option as shown by [6] Lu and Neftci (2008) is the European plain vanilla options which can be exercised at any time before maturity. Barrier option behaves like a plain vanilla option as long as the underlying asset price does not fall below or predefined barrier. The cost of barrier option as shown by [19] Hull (2003) falls below that of the plain vanilla option. Knock-in barrier options become plain vanilla option when a barrier is hit whereas knock-out barrier options is when the underlying is higher than the barrier. In this case, up-and-out barrier options are the simplest to calibrate.

Other studies focus on credit default swap which is a contract that provides insurance against a default by a sovereign entity and enhance financial stability. Credit derivatives are financial instruments managing default risk which occurs when there is a decline in the ability of the borrower to repay the debt. Credit default swap as suggested by [20] Hull and Allan (2003) allow sovereigns to manage credit risks by insuring against the default of borrowers. Furthermore, [21] Terzi and Ulucay (2011), [22] Duffee (1996), points out that credit default swaps enable the issuing country to transfer or redistribute its credit risks. Empirical findings suggest that the use of sovereign credit default swap spreads increase the level of liquidity hence reducing default risks.

A commodity derivative in the form of a plain vanilla put option should be attached to sovereign Eurobond to hedge the occurrence of a sovereign default risk. When commodity prices are increasing, [6] Lu and Neftci (2008), note that the default risk and borrowing cost decreases. In general, [22] Duffee (1996), finds that the increase in commodity price movements, reduces the default probability hence a bondholder will be compensated by paying for the default swap spread. Credit default swaps are actually put options and provide insurance against price decrease. However, the market for credit default swap in African countries is limited.

Modern studies have shown that Artificial Intelligence can be used in forecasting the applicability of innovative financing in the capital market using intelligent algorithms such as Artificial Neural Networks. The human intelligence includes learning, reasoning and problem solving, which is accomplished by studying how human brain thinks, and how humans learn, decide and work while trying to solve a problem. The ANNs gather their knowledge by detecting the 
patterns and relationships in data and learn (or are trained) through experience, not from programming.

\section{Theoretical Framework}

The model builds on the works of [6] Lu and Neftci (2008) who employ BlackScholes model (1973) to price plain vanilla European options. The option price is a function of asset's price volatility, risk free rate and strike price. The BlackScholes model continues to be the standard option pricing model. The well-known Black-Scholes formula for option pricing is only valid under the assumption of complete markets. Intuitively, Black-Scholes model is only valid under the assumption of complete markets where volatility is constant. The assumptions made when valuing options include the asset price being exogenous implying that price movements are not affected by actions of markets. The model has been criticized on its strict assumptions such as the constant volatility which is not realistic. Findings by [23] Bakshi et al. (1997), show that the Black-Scholes prediction of zero risk cannot be achieved. The value of call or put option depends on time to maturity, risk free interest rate, volatility, strike price and underlying asset price. The general Black-Scholes model for pricing European call option is given by:

$$
C_{t}=S_{t} N\left(\partial_{1}\right)-K \mathrm{e}^{-r T} N\left(\partial_{2}\right)
$$

where:

$C_{t}$ is the price of a European call option at time $t, S_{t}$ is the stock price, $K$ is the strike price, $r$ is the risk free interest rate, $t$ is the time to option expiration, $\sigma$ is the standard deviation of the option. The simplest financial option, is the European call option. If stock price is greater than the strike price at expiry, then it pays off to exercise call option. The option prices are derived using the general [9] Black-Scholes (1973) formula, where the spot price equals the present value of the striking price, as shown by [6] Lu and Neftci (2008), is given by:

$$
C_{t}(s, t, K, r, \sigma)=S N\left(d_{1}\right)-K \mathrm{e}^{-r T} N\left(d_{2}\right)
$$

where $N\left(d_{1}\right)$ and $N\left(d_{2}\right)$ are the cumulative distribution function of a standard normal random variable.

$$
d_{1}=\frac{\log \left(\frac{S_{0}}{K}\right)+\left(r+\frac{\sigma^{2}}{2}\right) T}{\sqrt[\sigma]{T}}, d_{2}=\frac{\log \left(\frac{S_{0}}{K}\right)+\left(r-\frac{\sigma^{2}}{2}\right) T}{\sqrt[\sigma]{T}}=d_{1}-\sqrt[\sigma]{T}
$$

where $C_{t}$ denote the price of a European call option at time $t, S$ is the stock price, $K$ is the option striking price, $r$ is the risk free interest rate, $t$ is the time to option expiration, $\sigma$ is the standard deviation of the option and $N($.$) is the cumulative$ distribution function of a standard normal random variable $N(0,1)$. For the special case of a European call or put option, Black-Scholes model indicate that a hedged position can be created consisting of a short position in the option and a long position in the underlying where option's value will not depend on the price of the underlying. In addition, [22] Duffee (1996), note that put call parity 
can also consist of a long position in a credit default swap combined with a long position in the underlying. Other studies define put-call parity as a relationship between the price of a European call and put option with identical strike prices and maturity time in a frictionless market is given by

$$
P_{t}=K \mathrm{e}^{-r T} N\left(-\partial_{2}\right)-S_{t} N\left(-\partial_{1}\right)
$$

where $C_{t}$ denote the price of a European call option at time $t, S$ is the stock price, $K$ is the option striking price, $r$ is the risk free interest rate, $t$ is the time to option expiration, $\sigma$ is the standard deviation of the option and $N($.$) is the cumulative$ distribution function of a standard normal random variable $N(0,1)$.

The price $P_{t}$ of a European put option at time $t$ with the same expiry date $T$ and strike price $K$ can be obtained by the following put-call parity relationship

$$
C_{t}-P_{t}=S_{t}-K \mathrm{e}^{-r(T-t)}
$$

$P_{t}$ is the current stock price.

Solving partial differentiation equations in closed form is difficult but in the case of Black Scholes model, the European call option at time $t=0$ is

$$
V_{0}=S_{0} N\left(d_{1}\right)-K \mathrm{e}^{-r t} N\left(d_{2}\right)
$$

European put option is given by:

$$
\begin{gathered}
V_{0}=K \mathrm{Ke}^{-R t} N\left(-d_{2}\right)-S_{0} N\left(-d_{1}\right) \\
d_{3}=\frac{\log \left(\frac{S_{0}}{S_{b}}\right)+\left(r+\frac{\sigma^{2}}{2}\right) T}{\sqrt[\sigma]{T}} \\
a=\left(\frac{S_{0}}{S_{b}}\right)^{-1+\left(\frac{2 r}{\sigma^{2}}\right)}, \quad b=\left(\frac{S_{b}}{S_{0}}\right)^{1+\left(\frac{2 r}{\sigma^{2}}\right)}
\end{gathered}
$$

When a financial security is traded, the buyer is said to take a long position in the security and the seller is said to take the short position in the security. The derivative pricing problem is solved by determining a fair value for a derivative. Two boundaries on $s(t)$ are 0 and $\infty$ representing maximum and minimum price of the underlying asset. Black-Scholes model is also used to price barrier options which behave like a plain vanilla option as long as the underlying asset price does not fall below or predefined barrier. As noted by [19] Hull (2003), the cost of barrier option falls below that of the plain vanilla option. Knock-in barrier options become plain vanilla option when a barrier is hit whereas knock-out barrier options is when the underlying is higher than the barrier. Thus, knock-ins and knock-outs features make options cheaper and fills shortcomings of risk reversals hence, barrier options are suitable for hedging commodity price risk. However, up-and-out barrier options are the simplest to calibrate. Under suitable assumptions, the value of the contract really depends only on $t$ and $S$, and it satisfies the following partial differential equation: 


$$
\frac{\mathrm{d} f}{\mathrm{~d} t}+\frac{1}{2} \sigma^{2} S^{2} \frac{\mathrm{d}^{2} f}{\mathrm{~d} S^{2}}+r S \frac{\mathrm{d} f}{\mathrm{~d} S}-r f=0
$$

where $r$ is the risk-free interest rate, $\sigma$ is the volatility of the underlying asset, $S(t)$ is the current price at time $t$. The value of a European option has three components, the intrinsic value, the striking price of the option and the insurance value. The intrinsic value is the difference between the price of the underlying asset, $S$. The striking or exercise price, $K$ is the payoff from exercising option only on the expiration date and the option's premium is the payment for option upfront.

The barrier option behaves like a plain vanilla option as long as the underlying asset price does not fall below or predefined barrier, $S_{b}$. In up-and-out options, they are active when $S_{b}>S$ as long as the underlying asset price crosses and falls below a predefined barrier, $S_{b}$. The rationale for barrier options is that by putting a barrier, the payoff is limited. If both down-and-in and down-and-out are held then the effect of the barrier is cancelled and the two barrier options are equivalent to a vanilla put option.

\section{Data Description}

This study employs monthly data in which the commodity prices for oil, gold and silver are from the IMF IFS for Tanzania (Gold), Copper (Zambia) and Oil (Nigeria). Commodities such as gold, oil and silver are used because they are highly volatile. The volatility and the risk free interest rate measured by the 10 year US treasury bill are from Bloomberg for the month of December 2012. The "strike" price implies percentage of the underlying price. The option prices, interpreted as the percentage of the underlying nominal amount, are derived using the Black-Scholes formula [9] (Black and Scholes, 1973).

\section{Black Scholes Results}

In vanilla options, a put option and a call option provides insurance against commodity price shocks. A put option acts as a price floor by providing insurance against price decrease. [6] Lu and Neftci (2008), argue that a call option acts as a price ceiling by providing insurance against price increase so they both set minimum and maximum price. Table 1 lists the prices of at-the-money (ATM) options on the three selected commodities. According to [24] Rauch et al. (2013), commodities such as crude oil is one of the mostly traded and volatile in the world.

As shown in Table 1, prices of at the money put options are relatively higher than out of the money put options. If the reference entity, in this case, the government wants to hedge commodity price risks, they will use the less costly options. Hence, OTM put options will be the alternative instrument to ATM put options which is in line with findings by [6] Lu and Neftci (2008). By buying OTM put options to insure an underlying asset, the government sets a minimum price floor to prevent any loss from price declines. However, option traders usually rebalance their portfolios by selling other options such that the gains 
from selling these options will lower the cost of buying other options. [25] Carry and $\mathrm{Wu}$ (2003), indicate that short term options are more volatile when hit with shocks than long-term options. Thus short term options increase more than long-term options. Table 2 lists the prices of out-the-money (OTM) options on the three selected commodities.

These prices, OTM put options are less expensive that the ATM put options. OTM put options occur when the strike price of a put option is greater than the spot price of the underlying asset. However, risk reversals being part of the plain vanilla options, are still inefficient to reduce option costs. [25] Carry and Wu (2003), examine the behavior of both the prices of at-the-money and out-of-the-money options as the option's time-to-maturity tends to zero. They conclude that as the maturity tends to zero for OTM options, they exhibit a jump component implying that OTM put options are more liquid than OTM call options. Standard call (put) option contracts promise to pay nothing if they are out of the money at maturity. Since plain vanilla put options and risk reversals are inefficient as suggested above, up-and-out barrier options are considered to hedge commodity price risks. The prices for up-and-out put barrier options at 1 year and 3 year maturity are given in Table 3 .

Table 1. Prices of at the money put options.

\begin{tabular}{ccccc}
\hline Commodity & Strike price $(\mathrm{K})$ & Volatility $(\sigma)$ & $\begin{array}{c}\text { Price of 1-year } \\
\text { maturity }\end{array}$ & $\begin{array}{c}\text { Price of 3-year } \\
\text { maturity }\end{array}$ \\
\hline Silver & 158.16 & $26.04 \%$ & 13.66 & 14.58 \\
Oil & 111.07 & $28.95 \%$ & 14.80 & 10.40 \\
Gold & 137.56 & $13.78 \%$ & 11.28 & 9.65 \\
\hline
\end{tabular}

Source: IMF, IFS and Bloomberg for the month of December 2012. Note that at the money put option is when the underlying is equal to the strike price at a given period of time.

Table 2. Prices of $20 \%$ of out of the money put options.

\begin{tabular}{cccccc}
\hline Commodity & Stock price & $\begin{array}{c}\text { Strike price } \\
(\mathrm{K})\end{array}$ & $\begin{array}{c}\text { Volatility } \\
(\sigma)\end{array}$ & $\begin{array}{c}\text { Price of 1-year } \\
\text { maturity }\end{array}$ & $\begin{array}{c}\text { Price of 3-year } \\
\text { maturity }\end{array}$ \\
\hline Silver & 158.16 & 138.16 & $26.04 \%$ & 7.86 & 8.30 \\
Oil & 111.07 & 91.07 & $28.95 \%$ & 11.94 & 8.51 \\
Gold & 137.56 & 117.56 & $13.78 \%$ & 9.60 & 8.01 \\
\hline
\end{tabular}

Source: IMF IFS and Bloomberg for the month of December 2012. Note that out of the money put option is when the underlying is higher than the strike price at a given period of time.

Table 3. Prices of the up-and-out put options: $H=120$.

\begin{tabular}{cccccc}
\hline Commodity & Stock price & Strike price & Volatility & $\begin{array}{c}\text { Price of 1-year } \\
\text { maturity }\end{array}$ & $\begin{array}{c}\text { Price of 3-year } \\
\text { maturity }\end{array}$ \\
\hline Silver & 158.16 & 138.16 & $26.04 \%$ & 1.09 & 0.9 \\
Oil & 111.07 & 91.07 & $28.95 \%$ & 3.85 & 7.8 \\
Gold & 137.56 & 117.56 & $13.78 \%$ & 1.48 & 0.99 \\
\hline
\end{tabular}

Source: IMF, IFS and Bloomberg for the month of December 2012. Note that up-and-out put option is when the underlying exceeds the barrier, $\mathrm{H}$. 
Up-and-out put option prices are more effective than plain vanilla put options. An up-and-out call option pays off at maturity as long as the underlying hits the barrier or exceeds the barrier at any time before expiring. [6] Neftci and $\mathrm{Lu}$ (2008), show that the knock-ins and knock-outs features in the barrier options are an added advantage over risk reversals and plain vanilla options because they are cheaper and offset shortcomings of other options. Thus, knock-ins and knock-outs features make options cheaper and fills shortcomings of risk reversals hence, barrier options are suitable for hedging commodity price risk. In addition, when the barrier is crossed, the option's strike price becomes a knock-out option. [26] O'Hara et al. (2013), shows that when asset price falls, the holder cant exercise the call. This situation makes hedging difficult such as up-and-out call options.

\subsection{The Partial Derivatives}

The traditional Black-Scholes model uses partial derivatives to analyze the sensitivity of option premium to small changes in the model's parameters known as the Greeks. These hedging parameters are considered to be useful descriptive statistics to option traders for a portfolio. Within the Black-Scholes model, these sensitivities are obtained by taking the partial derivatives of the option-pricing formula below.

Table 4 reports the sensitivities of the options to changes in the model's parameters. The delta is the most important Greek because it has the largest risk. The delta of a call option on a stock is the rate of change of the option premium to change in stock price. Above result show that delta is the most volatile parameter implying that a $1 \%$ change in stock price, the option price changes by $90 \%$. Delta hedging involves the buying and selling the underlying asset to eliminate risk. The second Greek parameter is the $I$ gamma which is the rate of change in delta to change in the stock price.

If gamma is small, delta becomes less sensitive whereas if gamma is large, then delta becomes more sensitive to variations in the underlying. It implies that a $1 \%$ change in stock price, delta changes by $10 \%$. Delta and gamma hedging are both based on the assumption that the volatility of the underlying is constant. The $\rho$ rho is highly volatile that is a small change in interest rate leads to a significant change in the option price. Our results show that a $1 \%$ change in interest rate, the call price will vary by $8 \%$. When interest rates increase, call prices increase

Table 4. The Greeks.

$\begin{array}{cc}\text { The delta of a call option }(\Delta) & 0.90 \\ \text { The gamma of a call option }(I) & 0.10 \\ \text { The rho of a call option }(\rho) & 0.80 \\ \text { The theta of a call option }(\Phi) & 0.31 \\ \text { The vega of a call option }(\Upsilon) & 0.39\end{array}$

Source: IMF, IFS and Bloomberg for the month of December 2012. 
too but put prices decline. However, the theta, $\Phi$ which is the rate of change of option price to changes in time is less sensitive. The theta of a call option on time is 0.31 which indicates that a $1 \%$ change in time, the value of option price will vary by $31 \%$.

Similarly, the vega, $r$, which measures the sensitivity of option premium to changes in volatility shows that a $1 \%$ change in volatility leads to a change in option price by 39\%. According to [19] Hull (2003) and [27] Wilmott (2000), options are viewed as instruments of volatility in the underlying price, which leads to gamma gains and vega gains. An increase in volatility will increase the option price and a decrease in volatility, will decrease the option price in the same rate. Therefore, the Greeks provide traders a descriptive summary of determining the sensitivity of options with respect to fluctuations in stock prices, volatility, interest rate and time to maturity.

\subsection{The Fluctuation of Commodity Prices (1971-2012)}

Developing countries depend heavily on primary commodities for their export earnings which exposes them to commodity price shocks. The commodity price shocks are persistent and highly volatile which is the most challenging issues facing policymakers in heavily indebted countries. [28] Senhadji (2003), note that the borrowing behaviour of a developing country that relies heavily on primary commodities for its export earnings is faced with a uncertainty about the longevity of external shocks. Uncertainty concerning the longevity of shocks generates substantial debt accumulation. However, [2] Muhanji and Ojah (2011), note that external shocks significantly influence debt accumulation in African countries. Over-borrowing during the 1970s was the result of developing countries' favourable commodity prices which in the long-run, deteriorated.

Figure 1 and Figure 2 show the commodity price for gold and oil which are very volatile in the 1970's and 1980's. Some studies argue that the fluctuations is due to commodity price booms which prompted developing countries to overborrow. These favourable condition were short-lived as a result, high world interest rate and declining commodity prices contributed to sovereign defaults in early 1980s. However, some findings by [29] Akram (2009), indicate that that commodity price increase significantly in response to reductions in real interest rates. The evidence also suggests that the depreciation of the exchange rate increases export earnings. [30] Narayan and Liu (2011), investigate whether commodity price shocks on gold, silver and copper among others are persistent or short-lived. They find that only shocks to gold, silver, and copper are persistent. Similarly, [31] Cashin et al. (2002) investigates the duration and magnitude of cycles in world commodity prices where they note that price declines last longer than price booms. In this scenario, commodity prices have a downward trend in the long run.

These shocks to commodity prices have important implications for the many heavily indebted countries that are dependent on commodity exports. Price 


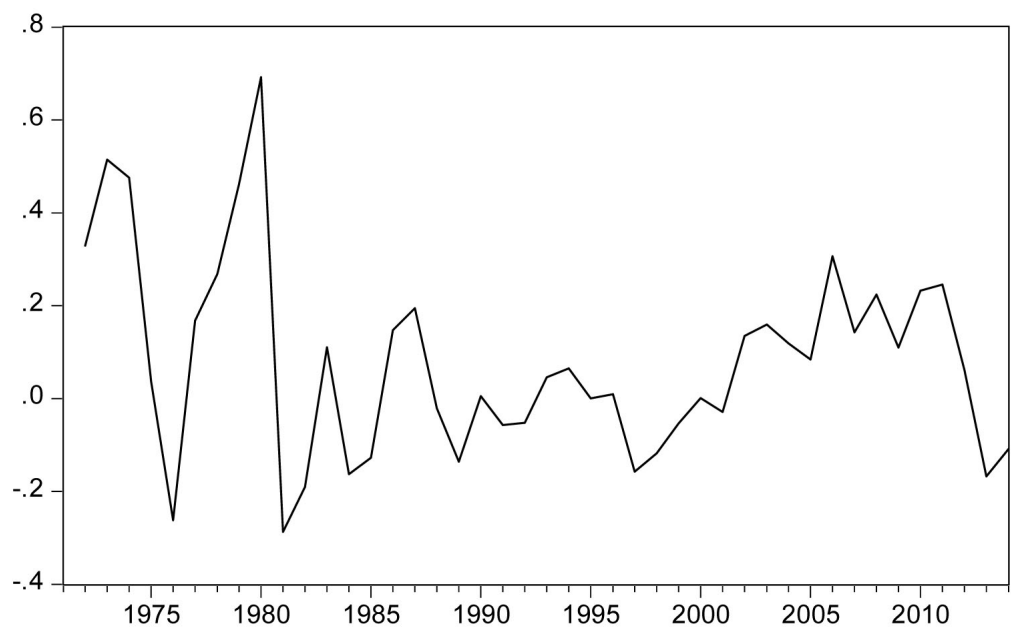

Figure 1. Commodity price for gold.

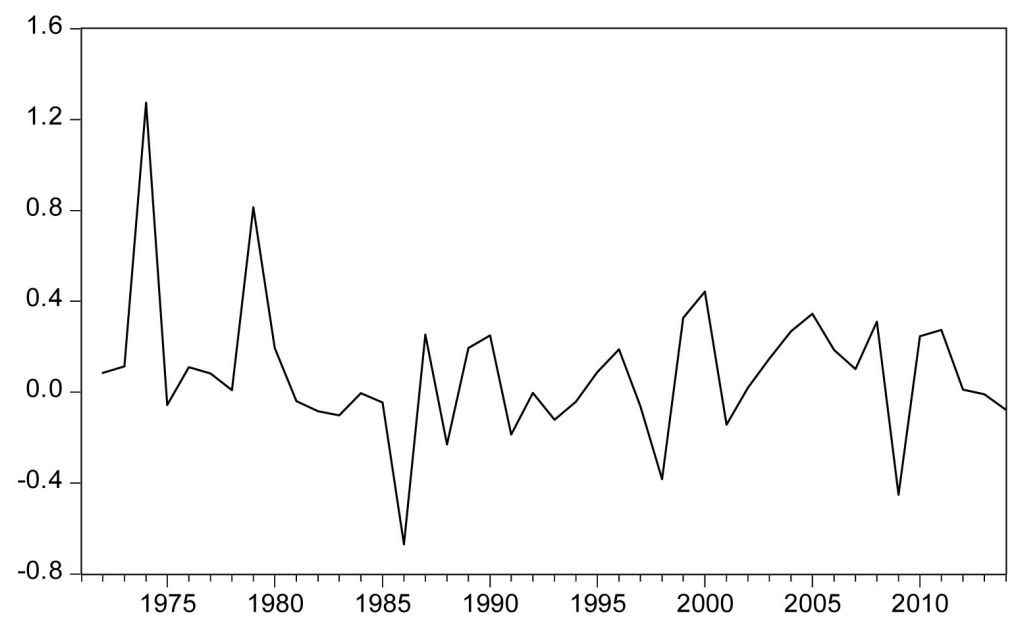

Figure 2. Commodity price for oil.

fluctuations makes export earnings uncertain especially when exchange rate appreciates and interest rate increases due to inflationary pressure. [2] Muhanji and Ojah (2011) investigate the extent to which external shocks lead to external debt accumulation in Africa. Their results show that both world commodity price and world interest rate shocks significantly affect external debt accumulation. While world commodity price shocks lead to an increase in external debt, world interest rate shocks improves the external debt burden.

However, [11] Kose and Riezman (2001) finds that world commodity price shocks are crucial in driving business cycles in particular the output fluctuations in less developed countries. [10] Cashin et al. (1999), say that world commodity prices play an important role in driving business cycles in Africa. Hence, African countries are prompted to pursue stabilization policies to minimize the effects of commodity price shocks. Stabilization policies in the form of buffer stock schemes are deliberated implemented in commodity-exporting countries to reduce the effects of volatile world commodity prices. 
Figure 3 and Figure 4 illustrate the commodity prices for copper and silver where silver is very volatile in the 1970's and 1980's meanwhile, copper's price is highly volatile in the late 2000s. This reflects that shocks are persistent over a long period of time leading to uncertainty in export earnings and external debt burden. [30] Narayan and Liu (2011), investigate whether commodity price shocks on gold, silver and copper among others are persistent or short-lived. They find that only shocks to gold, silver, and copper are persistent. Increase in commodity prices mostly stems from the combination of low central bank interest rates, the growth of sovereign wealth funds and the consequent lower demand for liquid assets.

Low levels of commodity prices in the late 1980s and in the 1990s may have played a role in some of the financial crises in commodity exporters emerging markets, deteriorating their current accounts. [32] Byrne et al. (2013), points out that the fluctuation of commodity price is an important aspect in fiscal and monetary policies especially the current account balance. These aspects carry important

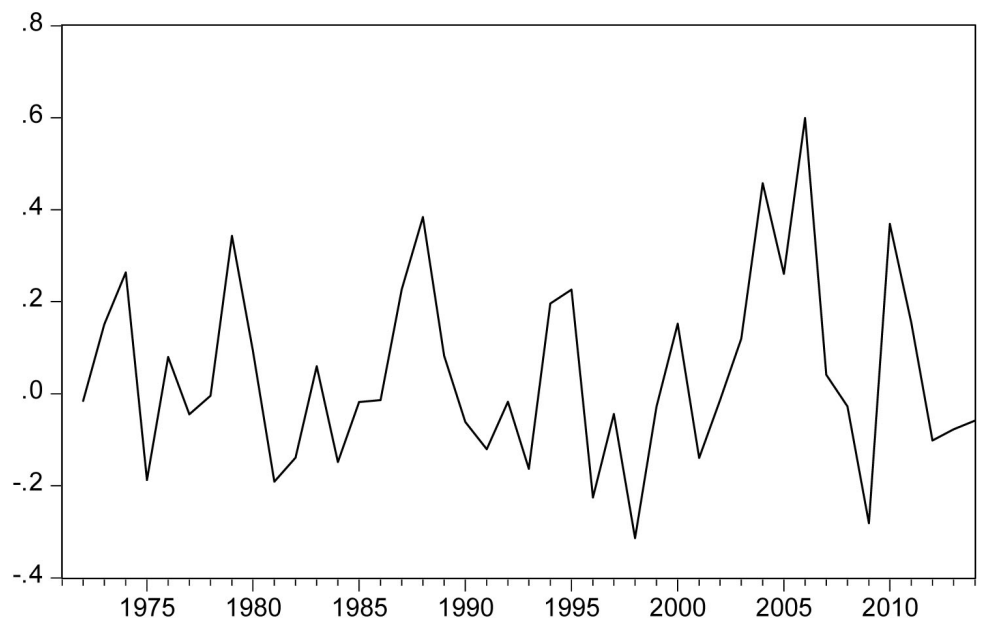

Figure 3. Commodity price for copper.

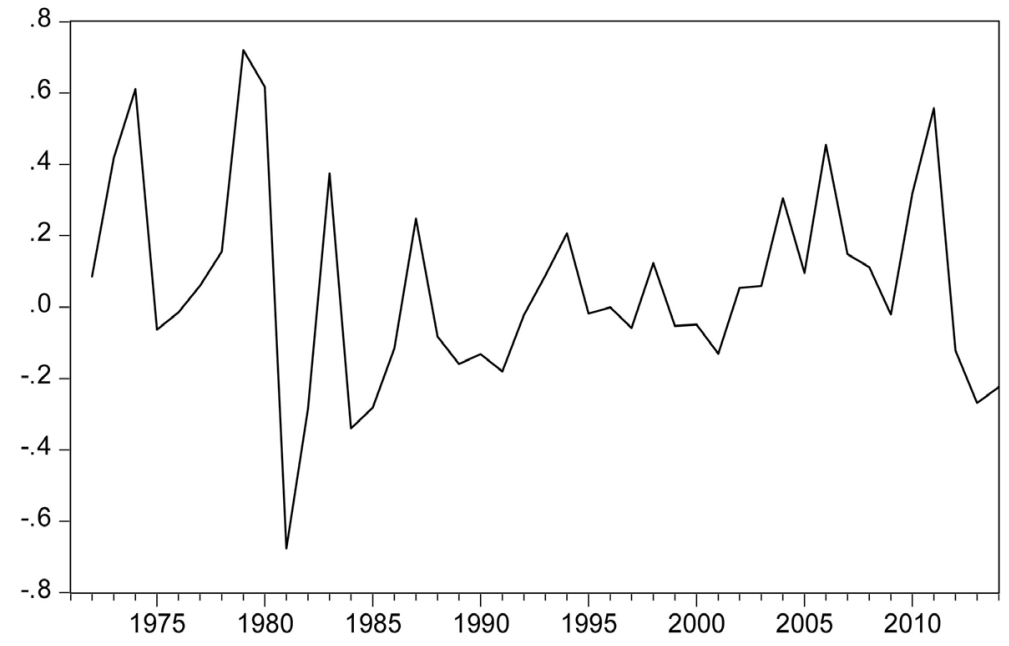

Figure 4. Commodity price for silver. 
welfare implications in that the persistence of commodity price shocks affects the effectiveness of stabilization policies.

Most of the deliberate attempts to stabilize commodity prices through the buffer stocks and buffer funds, have been unsatisfactory. [10] Cashin et al. (1999), note that stabilisation funds are inefficient in dealing with commodity price instability. In this case, policymakers shifted their focus to innovative risk management instruments that are only accessible in the world capital markets. As shown by [4] Daniel (2001), stabilisation funds are not efficient in stabilising commodity prices unless combined with expenditure restraints, since resources are limited. They propose to transfer risks to countries which can bear the commodity risks. However, [33] Borensztein and Panizza (2009), demonstrate that the welfare gains associated with hedging against commodity price risks are significant in influencing export earnings. Increase in export earnings will reduce external debt burden hence achieving macroeconomic stability.

\section{Conclusions}

This paper investigates the alternative financing instruments that can be used in the selected African countries to minimise the default risks and finance development. Hedging instruments minimize shocks that are hitting the economy while minimizing the likelihood of sovereign risks and defaults. Most of the developing countries are exposed to interest rate shocks and commodity price fluctuations lead to debt accumulation [34] (Demirguc-Kunt and Detrigiache, 1994), [2] (Muhanji and Ojah, 2011). However, the substantial financing needs require innovative financing and hedging instruments to reduce the cost of debt. This paper uses the standard model for pricing options, [9] Black-Scholes (1973) model to determine the fairly value of options.

The findings show that barrier options are the most cost-effective financing instruments to use especially the up-and-out barrier put options which is in line with findings by [6] Lu and Neftci (2008). Barrier options have an added advantage over the European plain vanilla options because of its knock-ins and knockouts features. However, prices of out of the money put options are more preferable to hedge commodity price risks because they are less expensive than ATM put options. In addition, [25] Carry and $\mathrm{Wu}$ (2003), note that short term options say one-year maturity are more volatile when hit with shocks than long-term options. Short term options for instance, OTM put options are more liquid than OTM call options. [26] O'Hara et al. (2013), that when asset price falls, the holder cant exercise the call. This situation makes hedging difficult especially using the up-and-out call options.

Our findings have several important policy implications. Firstly, African countries should mobilise domestic resources by developing their local bond market to access alternative financing instruments such as derivatives in the international capital market. As pointed out by [12] Mu et al. (2013) African bond markets are still small and illiquid to access hedging instruments that lower the 
sovereign default risks. Thus, it is important for policymakers to design sound financial instrument policies that will hedge sovereign risks and finance sustainable development. Secondly, African countries should use linked-bonds such as commodity linked bonds to minimize commodity price shocks. Third, African countries should be discouraged to borrow in foreign currency debt which is exposed to foreign exchange rate risks. In practice, foreign exchange rate risks are hedged through currency derivatives in the forex market. From the policy perspective, innovative financing instruments in African countries will assist policymakers in designing policies that will minimize the cost of debt and hedge sovereign risks.

\section{Conflicts of Interest}

The author declares no conflicts of interest regarding the publication of this paper.

\section{References}

[1] Hussein, K. and Mello, L. (2001) Is Foreign Debt Portfolio Management Efficient in Emerging Economies? Journal of Development Economics, 66, 317-335. https://doi.org/10.1016/S0304-3878(01)00165-1

[2] Muhanji, S. and Ojah, K. (2011) External Shocks and Persistence of External Debt in Open Vulnerable Economies: The Case of Africa. Economic Modelling, 28, 1615-1628. https://doi.org/10.1016/j.econmod.2011.02.020

[3] Mpapalika, J. and Malikane, C. (2019) The Determinants of Sovereign Risk Premium in African Countries. Journal of Risk and Financial Management, 12, 1-29. https://doi.org/10.3390/jrfm12010029

[4] Daniel, J. (2001) Hedging Government Oil Price Risk. IMF Working Paper 01/185, International Monetary Fund, Washington DC. https://doi.org/10.5089/9781451859416.001

[5] Dooley, M. (2000) Debt Management and Crisis in Developing Countries. Journal of Development Economics, 63, 45-58. https://doi.org/10.1016/S0304-3878(00)00099-7

[6] Lu, Y. and Neftci, S. (2008) Financial Instruments to Hedge Commodity Price Risk for Developing Countries. IMF Working Paper. https://doi.org/10.5089/9781451868685.001

[7] Price, R. (1997) The Rationale and Design of Inflation-Indexed Bonds. IMF Working Paper, WP/97/12, 1-69. https://doi.org/10.5089/9781451842869.001

[8] Collier, P. (2014) Attracting International Private Finance for African Infrastructure. Journal of African Trade, 1, 37-44. https://doi.org/10.1016/j.joat.2014.09.002

[9] Black, F. and Scholes, M. (1973) The Pricing of Options and Corporate Liabilities. Journal of Political Economy, 81, 637-659. https://doi.org/10.1086/260062

[10] Cashin, P., Liang, H. and McDermott, J. (1999) How Persistent Are Shocks to World Commodity Prices? IMF Staff Papers, 47, 177-217.

[11] Kose, A. and Riezman, R. (2001) Trade Shocks and Macroeconomic Fluctuations in Africa. Journal of Development Economics, 65, 55-80. https://doi.org/10.1016/S0304-3878(01)00127-4

[12] Mu, Y., Phelps, P. and Stotsky, J. (2013) Bond Markets in Africa. Review of Devel- 
opment Finance, 3, 121-135. https://doi.org/10.1016/j.rdf.2013.07.001

[13] Leigland, J. (2018) Public-Private Partnerships in Developing Countries: The Emerging Evidence-Based Critique. The World Bank Research Observer, 33, 103-134. https://doi.org/10.1093/wbro/lkx008

[14] Atta-Mensah, J. (2004) Commodity-Linked Bonds: A Potential Means for Less-Developed Countries to Raise Foreign Capital. Working Paper 2004-20, Bank of Canada, Ottawa.

[15] Myers, R. (1992) Incomplete Markets and Commodity-Linked Finance in Developing Countries. The World Bank Research Observer, 7, 79-94. https://doi.org/10.1093/wbro/7.1.79

[16] Schroder, M., Heinemann, F., Kruse, S. and Meitner, M. (2004) GDP-Linked Bonds as a Financing Tool for Developing Countries and Emerging Markets. ZEW Discussion Papers, No. 4-64, 1-63. https://doi.org/10.2139/ssrn.604444

[17] Chamon, M. and Mauro, P. (2006) Pricing Growth-Indexed Bonds. Journal of Banking and Finance, 30, 3349-3366. https://doi.org/10.1016/j.jbankfin.2006.06.007

[18] Borensztein, E. and Paolo, M. (2004) The Case for GDP-Indexed Bonds. Economic Policy, 19, 165-216. https://doi.org/10.1111/j.1468-0327.2004.00121.x

[19] Hull, J. (2003) Options, Futures, and Other Derivatives. 5th Edition, Prentice-Hall, Upper Saddle River.

[20] Hull, J. and Alan, W. (2003) The Valuation of Credit Default Swap Options. Journal of Derivatives, 10, 40-50. https://doi.org/10.3905/jod.2003.319200

[21] Terzi, N. and Ulucay, K. (2011) The Role of Credit Default Swaps on Financial Market Stability. Procedia Social and Behavioral Sciences, 24, 983-990. https://doi.org/10.1016/j.sbspro.2011.09.066

[22] Duffee, G. (1996) On Measuring Credit Risks of Derivative Instruments. Journal of Banking and Finance, 20, 805-833. https://doi.org/10.1016/0378-4266(95)00030-5

[23] Bakshi, G., Cao, C. and Chen, Z. (1997) Empirical Performance of Alternative Option Pricing Models. Journal of Finance, 52, 1-47. https://doi.org/10.1111/j.1540-6261.1997.tb02749.x

[24] Rauch, J., Krayzler, M., Brunner, B. and Zagst, R. (2013) Pricing of Derivatives on Commodity Indices. International Review of Financial Analysis, 29, 143-151. https://doi.org/10.1016/j.irfa.2013.02.006

[25] Carry, P. and Wu, L. (2003) What Type of Process Underlies Options? A Simple Robust Test. The Journal of Finance, 58, 2581-2610. https://doi.org/10.1046/j.1540-6261.2003.00616.x

[26] O’Hara, J., Sophocleous, C. and Leach, P. (2013) Symmetry Analysis of a Model for the Exercise of a Barrier Option. Communications in Nonlinear Science and Numerical Simulation, 18, 2367-2373. https://doi.org/10.1016/j.cnsns.2012.12.027

[27] Wilmott, P. (2000) Quantitative Finance. John Wiley and Sons, Hoboken.

[28] Senhadji, A. (2003) External Shocks and Debt Accumulation in a Small Open Economy. Review of Economic Dynamics, 6, 207-239. https://doi.org/10.1016/S1094-2025(02)00015-7

[29] Akram, Q. (2009) Commodity Prices, Interest Rates and the Dollar. Energy Economics, 31, 838-851. https://doi.org/10.1016/j.eneco.2009.05.016

[30] Narayan, P. and Liu, R. (2011) Are Shocks to Commodity Prices Persistent? Journal of Applied Energy, 88, 409-416. https://doi.org/10.1016/j.apenergy.2010.07.032

[31] Cashin, P., McDermott, J. and Scott, A. (2002) Booms and Slumps in World Commodity Prices. Journal of Development Economics, 69, 277-296. 
https://doi.org/10.1016/S0304-3878(02)00062-7

[32] Byrne, J., Fazio, G. and Fiess, N. (2013) Primary Commodity Prices: Co-Movements, Common Factors and Fundamentals. Journal of Development Economics, 101, 16-26. https://doi.org/10.1016/j.jdeveco.2012.09.002

[33] Borensztein, E. and Panizza, U. (2009) The Costs of Sovereign Default. IMF Economic Review, 56, 683-741. https://doi.org/10.1057/imfsp.2009.21

[34] Demirguc-Kunt, A. and Detrigiache, E. (1994) Interest Rates, Official Lending and the Debt Crisis: A Reassessment. Journal of Development Economics, 44, 263-285. https://doi.org/10.1016/0304-3878(94)90044-2 